\title{
ADDIE Model Application for Development of Teaching Material Based on Flipped Learning for Lecturer's in Polytechnic
}

\author{
N A A. Jalii ${ }^{1 *}$, A R Madar ${ }^{2}$, N I Kassim ${ }^{3}$ \\ ${ }^{1}$ Universiti Tun Hussein Onn Malaysia, \\ Batu Pahat Johor, 86400, MALAYSIA \\ *Corresponding Author
}

DOI: https://doi.org/10.30880/jstard.2020.02.03.020

Received 30 September 2020; Accepted 30 November 2020; Available online 31 December 2020

\begin{abstract}
The process of teaching and learning is an important element of ensuring that students are able to keep up with the content of the subject being presented. In order to attract student's interest and improve the student's academic achievement, the process of learning should be a fun and challenging process for students' thinking. The main issue of this study is that science and mathematics learning for some students is abstract and difficult to understand. This study aims at the development of teaching material based on flipped learning in Polytechnic. The findings of this study show that the development of teaching materials based on flipped learning involves all phases of ADDIE model namely analysis, design, development, implementation and evaluation. In this study, the teaching of flipped learning materials produced has gained the content of five experts in teaching and learning. The results show that the researcher has successfully produced teaching material that emphasizes the five main components of the active learning method, namely Jigsaw Puzzle, video presentation, Bingo Balls of Doom, Group Presentation, and Assignment Assessment. It is hoped that the development of teaching materials based on these flipped learning methods will enhance students' academic achievement and achievement and enable students to work together to make the learning process more meaningful.
\end{abstract}

Keywords: Teaching, flipped learning, application development, ADDIE model

\section{Introduction}

Education in Malaysia has changed dramatically and is now steadily increasing especially in the early 21 st century. These changes are in line with the country's economic growth from time to time. Learning at institutions of higher learning is formal learning that is based on the theory of achievement that is evaluated and validated by a particular party as well as recognition through the awarding of degrees. The goal of an institution of higher learning is to produce graduates who are successful in academic and personal achievement. Learning is a process related to cognitive, affective and psychomotor learning that occurs after student's experience training, interaction and experience of the environment resulting in changes in behavior, thinking and skills.

Teachers play an important role in controlling the teaching and learning process. This is because teachers are individuals responsible for student development and achievement (Yunos et al., 2019). Learning is generated when stimuli are processed and stored in memory to become experience and knowledge (Mok, 2000). Learning is a mental, physical or spiritual activity to the student. It is a process by which activities can change their attitudes and behaviors for continuous and lasting growth and the ability to use the knowledge and skills acquired for personal and social development and society or nation in general.

Student-centered learning is a teaching approach in which students influence content, activities, materials and learning rates (Froyd \& Simpson, 2010). According to Abdullah (2015) when student-centered learning is practiced, the 
burden of communication rests with the students and this is one of the broader learning approaches such as actively transforming the student's experience into learning, solving problems using creative and critical thinking, which also plays their role. - learning during the learning process, self-regulation techniques are also used and cooperative learning. Student-centered learning also provides students with independent learning opportunities and this enhances students' motivation, understanding and interest in the subject (O'neil \& McMahon, 2005).

Learning Science and Mathematics is often considered a difficult and boring subject for students. This problem is due to the traditional learning environment, poor answering skills among students, teacher-centered teaching and emphasis on memorizing theories or concepts as well as engaging in activities that do not attract students (Tahar et al., 2011). In addition, the attitude of students who do not want to ask makes the learning process unattractive (Ismaon, Iksan \& Othman, 2013). In the process of selecting a teacher's method, media and materials should be based on the three levels of student ability and learning objectives, namely selecting the appropriate method so that the teacher can attract and interest the student during the teaching and learning process. Next, a teacher should choose the learning and teaching medium so that the message or information he or she wants to convey can be understood by the student.

The problem is that Electrical Engineering subject 1 (DET1013) is one of the mandatory requirements for graduating students to take the Electric Circuit course (DET2033). The ministry has lowered its graduation rate to allow students to continue their study sessions next semester. As an example the score for graduating students who qualify for the next subject is 40- 43. This clearly indicates that the standards or quality of students to be born are lower and this indirectly contributes to the unemployment rate among Malaysian graduates. If a student who graduates in semester 1 has a low score, then he or she has no solid knowledge base. If this problem is not resolved quickly, it will cause TVET graduates produced by the polytechnic to not be compared to other graduates from other institutions. Therefore, it is important to use a variety of methods to enhance student interest so that students are actively involved throughout the teaching and learning process. Therefore, the objective of this study is for the development of teaching material based on flipped learning in Polytechnic.

\section{Flipped Learning}

Perez and Dong (2012) suggest that Flipped learning is a method by which students learn a subject outside the classroom while in the classroom students are exposed to active learning. Flipped learning means that the teacher-led teaching process has been implemented at home or outside the classroom while in the classroom teachers only discuss learning-related topics (Gerald, 2014). During the learning process in the classroom students only engage in discussion with the teacher. In this process the teacher acts only as a facilitator where the teacher will explain the lesson as needed by the student. The learning environment will also be student-centered.

Through the flipped learning method, students are able to self-administer all the necessary materials before they attend college (Johnson \& Renner, 2012). In addition, teamwork skills can be enhanced in the students, because in the classroom, students will be divided into groups and teachers will assign group assignments. This will indirectly allow teachers to approach students who have the problems. The next improvement is that teachers can make this flipped learning a teaching tool where teachers can use it for as long as there is no major change such as syllabus change and addition notes and exercises. Teachers will then receive quick feedback through this learning method as the teacher will identify students who have poor understanding without having to wait for the student to sit for the examination. Indirectly this will help the student to improve their academic achievement and interests.

\section{Methodology}

Generally, the ADDIE model has 5 phases whose first phase is Analysis, Design, Development, Implementation and Evaluation. The ADDIE model is a systematic approach to the process of designing instruction and helping designers to carry out the process with an organized framework to ensure their products are effective and efficient (Sanjaya, Suwatra \& Suartama, 2015). Therefore, in this study the development of teaching material based on flipped learning involved all phases of the ADDIE model. This is to ensure that the teaching materials developed are effective in increasing the interest of polytechnic students in Electrical Technology 1 (DET1013) lessons and working together to make the learning process more meaningful.

\section{Research Findings}

In this study, researchers have applied five phases of ADDIE model, namely, analysis, design, development, implementation and evaluation to develop teaching materials based on flipped learning and phase-based findings are as follows:

\subsection{Analysis Phase}

The Analysis Phase was conducted to obtain detailed research related information. The planned teaching and learning activities should be in line with the learning objectives. If a teacher focuses on the use of appropriate methods and media, new knowledge, skills and attitudes that students need to master. In a nutshell, in the context of designing 
material based on flipped learning, the process of analysis needs to involve three main aspects: student, teacher and teaching objectives. In seeking information related to these three aspects of the system, there are several key questions that can be asked during the analysis process:

- What is the background of students' knowledge of Electric Technology 1 (DET1013)?

- How far their mastery in Science and Mathematics the basis of Electrical Technology 1 (DET1013) lessons?

- What are the appropriate notes in Electrical Technology lesson 1 (DET1013) required?

- What activities are needed to further enhance student knowledge through active learning?

- What forms of effective teaching methodology are needed in delivering Electric Technology 1 (DET1013) lessons?

- What other disturbing and impactful issues can impede the teaching and learning process of Electric Technology 1 (DET1013)?

These questions are important for an early overview of the development of this teaching material.

\subsection{Design Phase}

The design covers system communication in general and process specifications and facilitates relevant stakeholders to understand the system's journey and evaluate its suitability and potential for developer development. Active learning encourages students to use their minds to study ideas, and to solve problems (Khatib, 2006). Active learning refers to students not only as listeners and take notes but students also need to participate in classroom learning. In this context, teaching and learning are student-centered while teachers act as facilitators only. Therefore, in the context of active learning, teachers play an important role in formulating effective teaching to enhance the achievement of their students. This teaching material emphasizes the five main components of the active learning method which are:

\subsubsection{Jigsaw Group Experts}

Jigsaw Group Experts are adapted from the Jigsaw Group learning method. Jigsaw Group Experts is a lecturer that divides students into groups and each group has different topic titles. Students are asked to have a discussion between them before they are re-divided into new groups. In this new group students have to explain and explain to their peers about the topic of the topic being discussed (Sugianti, 2016; Watson, 2009). In this way, students are trained to become experts in a particular topic. This is because the student must understand the topic in depth before explaining it to other peers (Kordaki \& Siempos, 2011). Through this kind of learning, lecturers can indirectly assist and train students to develop self-confidence when speaking in public and students can recognize their own learning styles (Darnon, Buchs \& Desbar, 2012 \& Mengduo \& Xiaoling, 2010).

According to Shume, Stander \& Grier, 2015, learning to use this jigsaw concept is able to build teamwork skills and create positive competition among students to achieve learning and teaching objectives. In addition, according to Darnon, Buchs \& Desbar (2012), students are also treated with a sense of responsibility within themselves. This is because students need to pass on the right information to their peers and to stimulate positive spirit in the classroom. According to Maden, 2010 \& Walker \& Crogan, 1998, students 'academic achievement can be improved and students' prejudice toward their peers can also be reduced. This is because students are trained to be self-sufficient for additional information.

\subsubsection{Video Shows}

With the rise of multimedia in education, video has become one of the most popular mediums for educators. The combination of several multimedia elements such as text, graphics and audio has proven to interest students and can stimulate visual and auditory perception (Ab Rahman, Zainal \& Ab Karim, 2015). This is also in line with the 21st Century learning of which one of the characteristics is to implement student-centered learning whereby the meaning of the teaching and learning role of the student is more important than the teacher whose role at the time was only as facilitator (Abdullah \& Ahmad, 2017)

The method of learning to use video as the primary medium enables teachers to present teaching easily, interestingly and positively (Sidek \& Hashim, 2016). In addition, it helps students to easily understand the learning process even when they are studying alone and without the presence of teachers. In addition, Mohd Nor \& Sharif (2014), teaching and learning using media aids such as structured teaching modules, workbooks, videos, visuals and so on can change students' positive behavior as students enjoy and enhance student understanding. According to Abdul Razak \& Abdul Rahman, 2013, students need to have a high level of reasoning as they have to overcome obstacles in achieving their learning objectives. 


\subsubsection{Bingo Balls of Doom}

Learning to use the Binggo Balls of Doom method is one of the interesting learning methods. This is because through this method there are elements of the game among the students. The games applied in mathematics can address students' negative attitudes and perceptions of mathematics where many students say that math is a difficult subject (Samsudin etc al, 2017). According to Mak Din et al, (2014), the application of the educational system using digital games techniques is very flexible and in fact has the advantage of applying the principles of learning that are the core of education such as the application of various elements as noted in behavioral theory, cognitive theory and constructive theory. Even through the elements of entertainment and fun present in the game package can actually stimulate the player's mind to realize that they have applied some of the concepts and skills they have learned before.

Further through this method also group learning can be applied. Each member of the group is fully responsible for ensuring that they are committed to sharing tasks to achieve their learning objectives (Yusri etc, 2012). According to Md Ibrahim etc al (2015), the elements of group learning can make students more motivated to conduct R\&D sessions. In addition, cognitive development can also be enhanced, through discussion and exchange of ideas within the student group to help students master learning concepts and to help students improve their thinking process.

Students are more responsible for ensuring the success of the group, they will be more interested in participating in the learning process and end up taking more responsibility (Jamaluddin etc al, 2016 \& Yusri etc al, 2012). This not only creates a positive attitude towards learning but also builds positive relationships among group members where each group member has different cultural and socio-economic backgrounds.

\subsubsection{Group Presentation}

Learning to use group presentations also captures students' interest and enhances student confidence. Lecturers who use this presentation during the PdP session are more likely to be favored by students than the PdP who use the "talk and chalk" method (Bartsch \& Cobern, 2003). According to Somasundram \& Mahamod (2017) \& Susskind (2004), learning through this method is a new and indirect method that enhances students' understanding, encourages students to think creatively and critically, enhances student achievement and motivation and even improves knowledge students constantly. In addition, Xingeng \& Jianxing (2012) \& Sidal (2003), inter-group collaboration enables productivity and quality to be enhanced in terms of combining the expertise, knowledge and commitment of all members and energies to produce a work that is minimized.

In addition to instilling interest and confidence among students, through this learning method students can apply values of respect and respect to each other (Mohamed Hussain, 2014 \& Village \& Keny, 2014) This is because other members of the group will remain silent and listen to their opinions or input their friends without questioning it. Respect can also be inculcated through the act of waiting for their turn to form opinions, views without interruption. In addition, Katip, Abu Bakr \& Malia, 2005, when students are given a responsibility to ensure the success of their group will be more interested in engaging directly in the activity and the good relationship between the group members. Active learners are also involved in developing an understanding of the material they are learning (Tarmuji, Abdullah \& Ahmad, 2015 \& Thomas, 2014).

In addition, Gambari, Joseph \& Balogun, 2015, stated that learning using this method can save time, as students will work together in groups to complete assigned tasks and in the short term allocate time. In addition, the cognitive achievement of technical students in engineering drawing subjects also improves when using slide point presentation methods. According to Brock \& Joglekar, 2011, students who are used to presenting in front of their peers have a bright potential in their field of work as they have instilled in them a sense of self-confidence and the ability to answer any questions they ask thoughtfully.

\subsubsection{Assignment Assessment}

Assignment assessments have been evaluated with various definitions. Assignment assessment is a process of obtaining information that is used to make judgments that are subsequently used in decision making (Ahmad \& Jinggan, 2015). Moreover, evaluation is the process of obtaining quantitative information. The assessment is divided into two formative and sumative evaluations. In addition, according to Veloo (2011) \& Prince (2004), defining is defined as a process undertaken to determine the effectiveness of teacher teaching and student mastery in a school-level course. Assessments also play an important role in the process of improving teacher teaching and learning in the classroom.

Group evaluation of tasks can improve the quality of the discussion (Rand, 2017 \& Spiller, 2009). This is because students will talk to each other to get the job done and get excellent marks. Indirectly, assessments in this way can increase students' understanding of the topics they want to solve. Therefore, Gibson \& Shaw (2011), assessing this assignment can also enhance students' internal motivation when teachers use this method. This is because, when students clearly understand the topic, their motivation and student confidence can also be increased. Assessment is not just about making decisions about a student's achievement, but on providing positive support and mechanisms to help students improve or improve their learning, improve lecturer teaching and contribute to the effectiveness of the program (Khalid, Ahmad \& Hamdan, 2015 \& Fitzsimons, 2014). 


\subsection{Development Phase}

The next phase is the system design phase to be developed. It covers the process of determining how learning works. Designers or developers of teaching materials will focus more on how a topic will be presented to students, system specifications and system storyboards. In this phase, a general overview of the teaching materials will be presented using visual methods. This is done by setting the system content, interface design, storyboards and flow charts for the system being developed. The design covers system communication in general and process specifications and facilitates relevant stakeholders to understand the system's journey and evaluate its suitability and potential for developer development.

Table 1 - Proposed development of teaching material based on flipped learning

\begin{tabular}{|c|c|c|c|c|c|}
\hline No. & Activity & Objective & Topic & Assignment & Activity \\
\hline 1 & Jigsaw Puzzle & $\begin{array}{l}\text { - Students understand the } \\
\text { basic symbols of } \\
\text { electrical components as } \\
\text { well as the differences } \\
\text { between cells and } \\
\text { batteries. } \\
\text { - Students learn the } \\
\text { differences for circuit } \\
\text { assembly (Series, } \\
\text { Parallel and } \\
\text { Combination) } \\
\text { - Students understand the } \\
\text { terms of electric current } \\
\text { and quantity of electric } \\
\text { current (current, Charge, } \\
\text { Potential Difference and } \\
\text { Resistance) } \\
\text { - Students explain the } \\
\text { main effects of electrical } \\
\text { current (Thermal Effects, } \\
\text { Magnetic Effects and } \\
\text { Chemical Effects) } \\
\text { - Students distinguish the } \\
\text { concepts of resistors and } \\
\text { resistance in electrical } \\
\text { currents. }\end{array}$ & $\begin{array}{l}\text {-Standard symbols for } \\
\text { electrical components } \\
\text { and the difference } \\
\text { between cells and } \\
\text { batteries. } \\
\text {-The effects of } \\
\text { different cell } \\
\text { connections (Series, } \\
\text { Parallel and Series- } \\
\text { Parallel). } \\
\text {-Electric current and } \\
\text { quantity of electricity } \\
\text { (Current, Charge, } \\
\text { Potential Difference } \\
\text { and Resistance). } \\
\text {-Main effects of } \\
\text { electric current (Heat } \\
\text { effect, Magnetic effect } \\
\text { and Chemical effect). } \\
\text {-Resistance and } \\
\text { Resistivity }\end{array}$ & & $\begin{array}{l}\text {-Discussions and } \\
\text { descriptions in } \\
\text { groups. } \\
\text { - Discussions } \\
\text { with lecturers }\end{array}$ \\
\hline 2 & Video Shows & $\begin{array}{l}\text { - Students compare } \\
\text { between Ohm's Law, } \\
\text { Series Circuit, Parallel } \\
\text { Circuit and Combined } \\
\text { Circuit. } \\
\text { - Students use Ohm's } \\
\text { Law, Series Circuit, } \\
\text { Parallel Circuit and } \\
\text { Combined Circuit to } \\
\text { solve questions posed by } \\
\text { lecturers. }\end{array}$ & $\begin{array}{l}\text {-Ohm's Law. } \\
\text {-Series Circuit } \\
\text { (Equivalent Series } \\
\text { Resistance and Voltage } \\
\text { Divider). } \\
\text {-Parallel Circuit } \\
\text { (Equivalent Parallel } \\
\text { Resistance and Current } \\
\text { Divider). } \\
\text {-Combination of Series } \\
\text { and Parallel Circuit. }\end{array}$ & & $\begin{array}{l}\text { - Discussions } \\
\text { with lecturers }\end{array}$ \\
\hline 3 & $\begin{array}{l}\text { Bingo Balls } \\
\text { of Doom }\end{array}$ & $\begin{array}{l}\text { - Students understand the } \\
\text { concepts of Delta-star } \\
\text { transformation, Star- } \\
\text { Delta Transformation } \\
\text { and Power and Electric } \\
\text { Power. } \\
\text {-Students apply existing } \\
\text { formulas to solve } \\
\text { problems given by } \\
\text { lecturers. }\end{array}$ & $\begin{array}{l}\text {-Delta -Star } \\
\text { Transformation } \\
\text {-Star-Delta } \\
\text { Transformation } \\
\text {-Electrical Power and } \\
\text { Energy }\end{array}$ & $\begin{array}{c}\text {-Electrical } \\
\text { Technology } \\
\text { Book } \\
\text { (Polytechnic } \\
\text { Series) } \\
\\
\text { - E-Learning } \\
\text { Books (Yanz } \\
\text { Book) }\end{array}$ & -Games. \\
\hline
\end{tabular}




\begin{tabular}{|c|c|c|c|c|}
\hline 4 & $\begin{array}{l}\text { Group } \\
\text { Presentation }\end{array}$ & $\begin{array}{l}\text { - Students understand the } \\
\text { Kirchoff Current Law, } \\
\text { Kirchoff Voltage Law, } \\
\text { Thevenin Theorem, } \\
\text { Norton Theorem and } \\
\text { Superposition Theorem. } \\
\text { - Students apply these } \\
\text { laws in solving problems } \\
\text { given. }\end{array}$ & $\begin{array}{l}\text {-Kirchoff's Current } \\
\text { Law } \\
\text {-Kirchoff's Voltage } \\
\text { Law } \\
\text {-Thevenin's Theorem } \\
\text {-Norton's Theorem } \\
\text {-Superposition } \\
\text { Theorem }\end{array}$ & $\begin{array}{c}\text { - Discussions in } \\
\text { groups } \\
\text { - Presentation }\end{array}$ \\
\hline 5 & $\begin{array}{l}\text { Assignment } \\
\text { Assessment }\end{array}$ & $\begin{array}{l}\text { - Students understand the } \\
\text { concept of maximum } \\
\text { power transfer within the } \\
\text { circuit. } \\
\text {-The student applies the } \\
\text { formula contained in the } \\
\text { title of the maximum } \\
\text { power transfer when } \\
\text { solving the problem } \\
\text { given by the lecturer. }\end{array}$ & $\begin{array}{l}\text {-Maximum Power } \\
\text { Transfer }\end{array}$ & $\begin{array}{l}\text {-Exercises } \\
\text { - Discussions }\end{array}$ \\
\hline
\end{tabular}

\subsection{Implementation Phase}

Upon completion of the development phase, the implementation phase will be implemented. At the beginning level, the teaching material will be tested by operating on the part of the student. This phase is intended to determine the strengths and weaknesses of the teaching materials developed. According to Aaron, Aris and Tasir (2003), this phase is to test the effectiveness of teaching materials and also to evaluate the suitability of ready-made teaching materials. In addition, this phase is needed to support students' understanding of the topic and to master the topic well. In order to carry out this process, a group of students and teachers who have the criteria set before the study is required for the implementation process. The proceeds from this phase will be used for the purpose of improvement or recovery before the actual handbook is used.

Implementation of this handbook using the ADDIE model is because it solves the problems encountered during the design process. This is also because this model has a systematic process in designing teaching materials.

The implementation stages in this manual are intended for improvement after they have been measured, tested and implemented. The elements tested at this level are:

- The state of the teaching staff during the teaching and learning process in achieving the teaching and learning objectives, the learning outcomes obtained by the students, the presentation skills used by the teachers, the activities and assignments of the teachers and students.

- Preparing for students with different learning styles such as active, reflective, visual and auditory. In addition, it includes soft skills such as communication skills, critical thinking skills and so on.

- Environmental conditions that include teaching aids, equipment for carrying out activities and assignments as well as years of teaching.

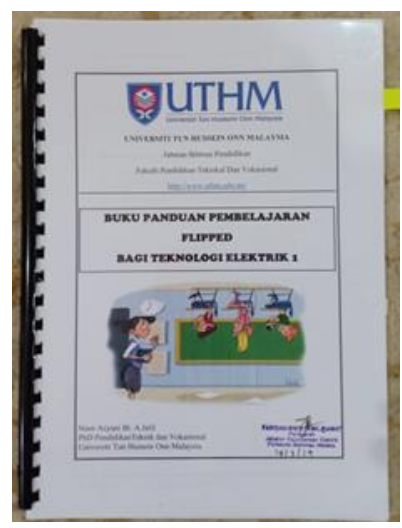

Figure 1 - Handbook of flipped learning methods implemented by researchers 

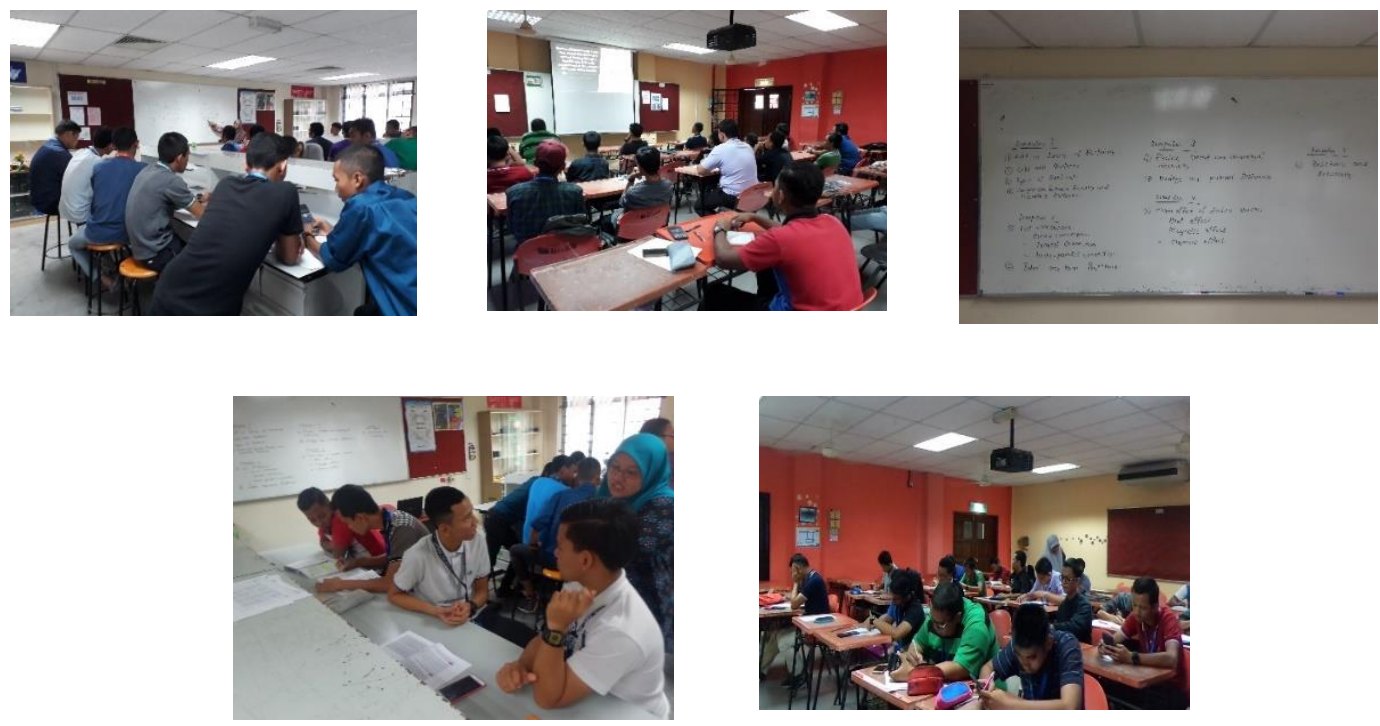

Fig. 2 - Activities which was conducted

\subsection{Evaluation Phase}

This evaluation phase is the final phase and in this phase it will evaluate the feasibility and effectiveness of the teaching materials based on the objective success stated in the analysis stage. In addition, it can measure and obtain student feedback on this teaching material. The evaluation phase consists of two assessments, namely formative evaluation and summative evaluation. Formative assessment refers to the assessment of the effectiveness of the design of the teaching materials as well as the development of the teaching materials. While summative assessment refers to the effectiveness of teaching by the teaching staff, achievement of learning objectives and learning outcomes. The resulting information will be used for the purpose of improving the teaching process for the same or different topics as well as for other relevant courses. Also, assessment from the point of view of student feedback is also required. It is assessed using a set of questionnaires as well as a set of pre and post questions related to the subject title. The data obtained as a result of the summative assessment are used to further the teaching and learning process. The use of the ADDIE Model in the construction of this teaching material is intended to create a good teaching material because the phases involved in this model make problems that arise and can be identified over time as they are designed and developed.
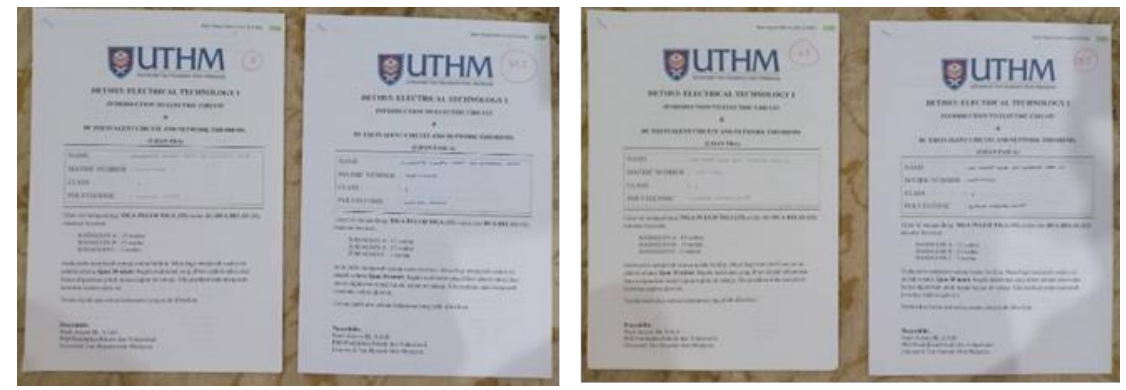

Fig. 3 - A set of pre and post questions that students have answered

\section{Conclusion}

Based on the discussions that have been presented, this shows that the ADDIE model covers five main phases of analysis, design, development, implementation and evaluation, which is a model of teaching material design that can be used to enhance student interest and academic achievement. This is proven because the phases contained in the ADDIE model have a comprehensive and systematic nature. The results show that the researcher has successfully produced teaching material that emphasizes the five main components of the active learning method, namely (i) Jigsaw Puzzle, (ii) Video shows, (iii) Bingo Balls of Doom, (iv) Group Presentation, (v) Assignment Assessment. It is hoped that the development of teaching materials based on flipped learning will enhance students' interest and academic achivements in learning and work together to make the learning process more meaningful. 


\section{Acknowledgement}

The author would like to express their gratitude to Universiti Tun Hussein Onn Malaysia for the assistance and the information provided to ensure the success of the study.

\section{References}

[1] Ab Rahman, H., Zainal, N. \& Ab Karim, N.A. (2015). Keberkesanan Penggunaan ICT di Dalam Pengajaran dan Pembelajaran Pendidikan Islam Bagi Sekolah Kebangsaan Desa Pandan Kuala Lumpur. Proceeding of IC-ITS 2015. Intenational Conference on Information Technology \& Society (238-252). Kuala Lumpur

[2] Abdul Razak, R. \& Abdul Rahman, M. (2013). Pembinaan Media Pengajaran Berasaskan Multimedia Di Kalangan Guru ICTL. Jurnal Kurikulum \& Pengejaran Asia Pasifik Bil 1, Isu 2. 20-31

[3] Abdullah, I. (2015). Pembelajaran Berpusatkan Pelajar dan Kaitannya Dengan Pembangunan Diri dan Peluang Pekerjaan. Kertas dibentangkan di Seminar Penyelidikan Pendidikan Guru Peringkat Kebangsaan 2004. http://umpir.ump.edu.my/id/eprint/943/

[4] Abdullah, S. \& Ahmad, N.S. (2017). Keberkesanan Aplikasi Youtube Dalam Pengejaran dan Pembelajaran Sains Kejuruteraan Di Politeknik Seberang Perai. E-Proceeding National Innovation and Invention Competition Through Exhibition 2017. (1-8)

[5] Abu, N.E. \& Eu, L.K. (2014). Hubungan Antara Sikap Minat, Pengajaran Guru dan Pengaruh Rakan Sebaya Terhadap Pencapaian Matematik Tambahan Tingkatan 4. Jurnal Kurikulum \& Pengajaran Asia Pasifik, Bil 2 Isu 1. $1-10$

[6] Ahmad, A. \& Jinggan, N. (2015). Pengaruh Kompetensi Kemahiran Guru Dalam Pengajaran Terhadap Pencapaian Akademik Pelajar Dalam Mata Pelajaran Sejarah. Jurnal Kurikulum \& Pengajaran Asia Pasifik Bil 3 Isu 2. 1-11

[7] Akcaoglu, M. \& Lee, E. (2016). Increasing Sosial Presence in Online Learning Through Small Group Discussions. International Review of Reasearch in Open and Distributed Learning Vol. 17, No.3. 1-18

[8] Bartsch, R.A. \& Cobern, K.M. (2003). Effectiveness of PowerPoint Presentations in Lectures. Journal of Computer \& Education 41. 77-86

[9] Brock, S. \& Joglekar, Y. (2011). Empowering PowerPoint Slides and Teaching Effectiveness. Journal of Information, Knowledge and Management Volume 6. 1-10

[10] Darnon, C., Buchs, C. \& Desbar, D. (2012). The Jigsaw Technique and Self-Efficacy of Vacational Training Students: A Practice Report. European Journal of Psychology of Education, Vol. 27, No. 3. 439-449

[11] Desa, S.B. \& Keny, M.S. (2014). PowerPoint versus Chalkboard Based Lectures in Pharmacology: Evaluation of Their Impact on Medical Student's Knowledge and Their Preferences. International Journal of Advanced Health Sciences Vol 1 Issue 5. 10-15

[12] Fitzsimons, M. (2014). Engaging Students' Learning Through Active Learning. Irish Journal of Academic Practice Volume 3 Issue 1. 1-27

[13] Froyd, J. \& Simpson, N. (2010). Student-Centered Learning Addressing Faculty Questions about Student Centered Learning. Kertas dibentang di Texas A\&M University. doi=10.1.1.526.348\&rep=rep1\&type=pdf

[14] Gambari, A.I., Yusuf, H.T. \& Balogun, S.A. (2015). Effectiveness of Powerpoint Presentation on Students Cognitive Achievement in Technical Drawing. Malaysian Online Journal of Educational Technology volume 3, issue 4. doi: v03i04/v03i04-01.pdf

[15] Gerald. R.O, (2014). The Flipped Classroom Model For College Algebra: Effect On Student Achievement. Colorado State University: Tesis Ph.D

[16] Gibson, K. \& Shaw, C.M. (2011). Assessment of Active Learning. The International Studies Encyclopedia, 1-16. doi: acrefore-9780190846626-e-120

[17] Harun, J., Aris, B. \& Tasir, Z. (2003). Pembangunan PerisianPengajaran: Satu Pendekatan Sistematik. Batu Caves: Venton Publishing

[18] Ismaon, Z., Iksan, Z. \& Othman, N. (2013). Kesan Pembelajaran Koperatif Model STAD Ke Atas Sikap Terhadap Matematik. Jurnal Pendidikan Matematik, 1 (1). 11-18

[19] Jamaluddin, J., Mohd Din, N., Nias Ahmad, M.A., Abdul Jabar, F., Mohamad Fadzillah, N.S. \& Husin, Z. (2016). Keberkesanan Kaedah Permainan dalam Pengajaran dan Pembelajaran Prinsip Perakaunan di Sekolah Menengah. KONAKA 2016. 53-57

[20] Katip, K., Abu Bakar, B. \& Malia, F.F. (2005). Tinjauan Pelaksanaan Pembelajaran Berkumpulan di Kalangan Pelajar Institusi Pengajian Tinggi Swasta (IPTS) di Johor Bahru. Seminar Pendidikan 2005 Fakulti Pendidikan UTM. (1-17). Universiti Teknologi Malaysia: Johor Bahru

[21] Khalid, R., Ahmad, J. \& Hamdan, A. (2015). Pembentukan Sikap Positif Guru Terhadap Pelaksanaan Aktiviti Pentaksiran. Journal of Personalized Learning, I (1). 77-84

[22] Kordaki, M. \& Siempos, H. (2011). A Collaborative and Adaptive Design Pattern of the Jigsaw Method within Learning Design- Based E- Learning Systems. Journal pf Technology-Enchanced Systems and Tools, SCI 350. 239-255 
[23] Maden, S. (2010). The Effect of Jigsaw IV on the Achievement of Course of Language Teaching Methods and Techniques. Educational Reaserch and Review Vol 5(12). 770-776

[24] Mak Din, H.A., Zainal Arifin, A.N., Mohamed Masrop, N.A., Mohamed, N.M. \& Ahmad, I.F. (2014). Permainan Pendidikan Digital: Satu Kajian Awal. Jurnal Sultan Alauddin Sulaiman Shah Bil 1. 20-27

[25] Md Ibrahim, L.F., Mohamad Yatim, M.H., Md Nasir, M. (2015). Menerokai Kemahiran Abad ke-21 KanakKanak dalam Proses Reka Bentuk Permainan Perceritaan Digital. Journal of Science, Mathematic and Technology Vol 2 No 1. 82-96

[26] Mengduo, Q. \& Xiaoling, J. (2010). Jigsaw Strategy as a Cooperative Learning Technique: Focusing on the Language Learners. Chinese Journal Of Applied Linguistics (Bimonthly) Vol 33 No 4. 113-125

[27] Mohamed Hussain, S. (2014). Keberkesanan Pembelajaran Kooperatif untuk Meningkatkan Motivasi Pelajar Dalam Pembelajaran Bahasa Melayu. Proceeding of the Global Summit on Education, GSE2014. (485-495). Kuala Lumpur: Malaysia

[28] Mohamed Noh, N., Abdullah, N., Teck, W.K., \& Hamzah, M. (2017). Keberkesanan Pendekatan Flipped Classroom dalam Pembelajaran Sains Di Sekolah Rendah. Jurnal Pendidikan Sains \& Matematik Malaysia Vol 7, No 2. 106-118

[29] Mohd Nor, A. \& Sharif, S. (2014). Penggunaan Bahan Visual di Kalangan Guru Teknikal. Jurnal Pemikir Pendidikan Vol 5. 79-98

[30] Musa, K. \& Abd Halim, H. (2015). Kemahiran Interpersonal Guru dan Hubungan dengan Pencapaian Akademik Pelajar. Jurnal Pendidikan Malaysia 40(2). 89-99

[31] O'Neill, G. \& McMahon, T. (2005). Student Centered Learning: What Does It Mean For Students and Lecturers. Emerging Issues in the Practice of University Learning and Teaching.1-10. doi: researchgate.net/publication/241465214

[32] Perez, N.W. \& Dong, J. (2012). Flipping the Classroom: How to Embed Inquiry and Design Projects into a Digital Engineering Lecture. Proceedings of the 2012 ASEE PSW Section Conference. (1-17). Cal Poly- San Luis Obispo

[33] Prince, M. (2004). Does Acyive Learning Work: A Review of the Research. Journal of Engineering Education 93(3). 223-231

[34] Samsudin, N., Wan Mohd Rosly, W.N., Mohamad Japeri, A.Z.U.S., Mohd Abd Rahman, S. \& Syed Abdullah, S.S. (2017). Keberkesanan Permainan Interaktif dalam Mengatasi Masalah Kebimbangan Terhadap Matapelajaran Matematik di Kalangan Pelajar. International Academin Research Journal of Social Science 3 (1). 202-207

[35] Sanjaya, P., Suwatra, W. \& Suartama, K. (2015). Pengembangan Multimedia Interaktif dengan Menggunakan Model ADDIE pada Matapelajaran IPS Kelas VIII Semester Ganjil Tahun Pelajaran 2014/2015 Di SMP Negeri 2 Seririt. E-Journal Edutech Universitas Pendidikan Ganesha Jurusan Teknologi Pendidikan Vol: 3, No 1. 1-10.

[36] Shume, T., Stander, E. \& Grier, A.S. (2015). The Jigsaw Method and Cooperative Learning. SESYNC Collection from 2013-2015. 1-6. doi: file $=1 \&$ type $=$ node $\&$ id $=1736 \&$ force

[37] Sidal, A. (2003). Kerja Berpasukan: Strategi ke Arah Keberkesanannya. Jurnal Pengurusan Awam Jilid 2 Bilangan 1. 68-83

[38] Sidek, S. \& Hashim, M. (2016). Pengajaran Berasaskan Video dalam Pembelajaran Berpusatkan Pelajar: Analisis dan Kajian Kritikal. Journal of ICT in Education (JICTIE) ISSN 2289-7844 Vol 3. 24-33

[39] Somasundram, B. \& Mohamod, Z. (2017). Keberkesanan Pembelajaran Koperatif Terhadap Pencapaian Dan Motivasi Murid Sekkolah Menengah Dalam Pembelejaran Bahasa Melayu. Jurnal Pendidikan Bahasa MelayuJPBM Vol 7, Bil 1. 11-23.

[40] Spiller, D. (2009). Assessment. Feedback to Promote Student Learning. Teaching Development Unit: The University of WAIKATO. 1-19

[41] Sugianti (2016). The Implementation of Jigsaw Technique to Teach Poetry of Buya Hamka. IOSR Journal of Research \& Method in Education (IOSR_JRME). 65-68

[42] Susskind, J.E. (2004). PowerPoint's Power in the Classroom: Enhancing Student's Self-efficacy and Attitudes. Journal of Computer \& Education 45, Issue 2. 203-215

[43] Tahar M.S, Esa A, Rahim M.B, Baser J.A, Shuib S, Buntat Y (2011). Keberkesanan Penggunaan CD Interaktif Lukisan Isometrik Terhadap Kemahiran Visualisasi Pelajar. Journal Of Technical Vocational \& Engineering Volume 3. 104-115

[44] Tarmuji, N.H., Abdullah, N.M. \& Ahmad, S. (2015). Strategi Pembelejaran Matematik Secara Berkumpulan: Satu Kajian Perbandingan. KONAKA 2015. 177- 181

[45] Thomas, M.M. (2014). Acting Out in Class: The Group Role-Play Advantage Over PowerPoint Presentations. Journal of Legal Studies in Business Volume 19. 118-128

[46] Veloo, A. (2011). Keupayaan Teori dan Pelaksanaan Petaksiran dalam Pembelajaran. Journal of Governance and Development Vol 7. 8-15

[47] Walker, I \& Crogan, M. (1998). Academic Performance, Prejudice, and The Jigsaw Classroom: New Pieces to the Puzzle. Journal of Community \& Applied Social Psychology, 8. 381-393

[48] Watson, N.E. (2009). The Benefirs of Active Learning Trough Discussion in an Advanced Classroom. Master Teacher Program by The Center for Teaching Excellence. United States Military Academy: West Point NY. 
[49] Xingeng, D. \& Jianxing, L. (2012). Advantages and Disadvantages of PowerPoint in Lectures to Science Students. I.J. Education and Management Engineering 2012 Volume 9. 61-65

[50] Yadzi, M. (2012). E-Learning Sebagai Media Pembelajaran Interaktif Berbasis Teknologi Informasi. Jurnal Ilmiah Foristek Vol. 2, No. 1. 143-152

[51] Yusri, G., Mohd Rahimi, N., M. Shah, P., Wah, W.H. \& Thalal Hassan, A. (2012). Penggunaan Strategi Belajar Bersama Rakan Dalam Kalangan Pelajar Kursus Bahasa Arab di Universiti Teknologi Mara (UiTM). Asia Pacific Journal of Educators and EducationVol 27. 37-50 